\title{
LINHAS GERAIS DA DESCONSIDERAÇÃO DA PERSONALIDADE JURÍDICA NA DISSOLUÇÃO IRREGULAR A EMPRESA
}

\section{GENERAL LINES OF DISREGARD FOR THE LEGAL PERSONALITY ON IRREGULAR DISSOLUTION THE COMPANY}

\begin{abstract}
${ }^{1}$ Fábio Augusto Barcelos Moreira Corrêa
${ }^{2}$ Tereza Cristina Monteiro Mafra

\section{RESUMO}

A proposta do presente artigo é analisar o cabimento do instituto da desconsideração da personalidade jurídica nas situações que envolvam a dissolução irregular da empresa de responsabilidade limitada, à luz da jurisprudência do STJ. Destaca-se os impactos que novo Código de Processo Civil proporcionará ao instituto em análise para resguardar a autonomia patrimonial da pessoa jurídica, assim como a garantia do devido processo legal e da ampla defesa, impactando diretamente no Direito Empresarial. A análise visa contribuir para a compreensão do instituto em estudo, assim como a nova sistemática processual para o seu cabimento. Adotando-se a metodologia dialética e crítica.
\end{abstract}

PAlAVRAS-CHAVE: Novo Código de Processo Civil; Desconsideração da personalidade jurídica; Dissolução irregular da empresa; Direito Empresarial.

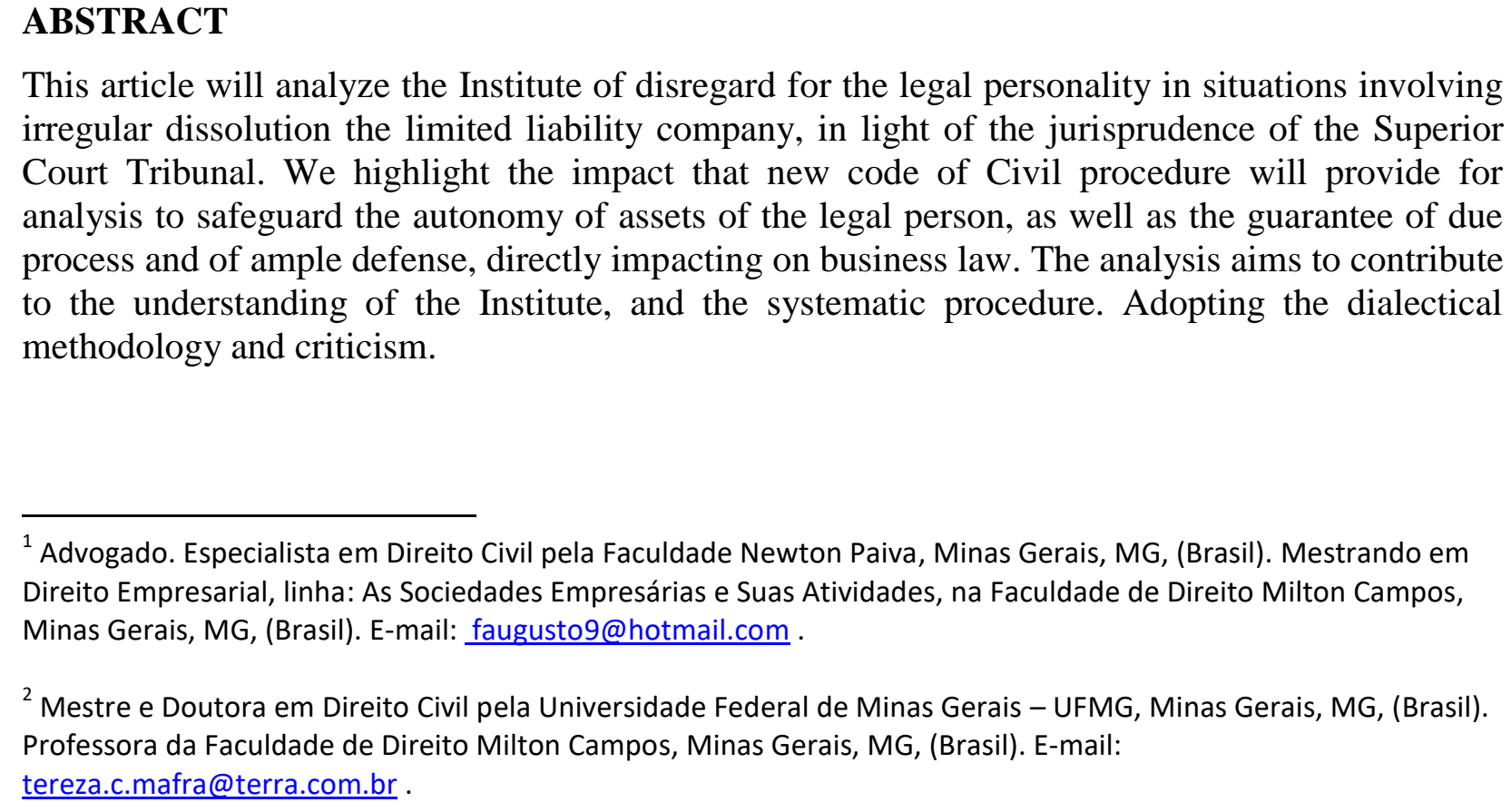

This article will analyze the Institute of disregard for the legal personality in situations involving irregular dissolution the limited liability company, in light of the jurisprudence of the Superior Court Tribunal. We highlight the impact that new code of Civil procedure will provide for analysis to safeguard the autonomy of assets of the legal person, as well as the guarantee of due process and of ample defense, directly impacting on business law. The analysis aims to contribute to the understanding of the Institute, and the systematic procedure. Adopting the dialectical methodology and criticism.

\footnotetext{
${ }^{1}$ Advogado. Especialista em Direito Civil pela Faculdade Newton Paiva, Minas Gerais, MG, (Brasil). Mestrando em Direito Empresarial, linha: As Sociedades Empresárias e Suas Atividades, na Faculdade de Direito Milton Campos, Minas Gerais, MG, (Brasil). E-mail: faugusto9@hotmail.com .

${ }^{2}$ Mestre e Doutora em Direito Civil pela Universidade Federal de Minas Gerais - UFMG, Minas Gerais, MG, (Brasil). Professora da Faculdade de Direito Milton Campos, Minas Gerais, MG, (Brasil). E-mail: tereza.c.mafra@terra.com.br.
}

Revista Brasileira de Direito Empresarial -le-SSN: 2526-0235| Curitiba | v. 2 | n. 2 | p. 97 - 116 | Jul/Dez. 2016. 
KEYWORDS: New CPC; Disregard of legal Entity; Irregular company's Dissolution; Business Law

\section{INTRODUÇÃO}

O desenvolvimento do presente artigo baseia-se na compreensão das Sociedades Empresárias de responsabilidade limitada, dotada de personalidade jurídica própria e autonomia patrimonial, que goza de aptidão genérica para adquirir direitos e contrair obrigações, respondendo seu património pela dívida contraída pela sociedade, afastando-se a responsabilidade dos sócios, em razão da separação patrimonial.

Entretanto, a limitação da responsabilidade dos sócios não é absoluta, podendo ser afastada mediante condutas de abuso de poder, fraude a terceiros ou confusão patrimonial.

O objetivo é analisar com ênfase na jurisprudência do Superior Tribunal de Justiça (STJ) se a dissolução irregular de uma determinada sociedade limitada, por si só, autoriza a imediata aplicação do instituto da desconsideração da sua personalidade jurídica, assim como as contribuições que o novo Código de Processo Civil (CPC) apresenta ao tema, especialmente ao estabelecer o exercício do contraditório e da ampla defesa ao instituto em questão.

O problema é pensar a distinção existente entre os direitos adquiridos da sociedade empresária (autonomia patrimonial) e os direitos dos sócios (separação patrimonial), a fim de preservar a segurança jurídica e o empreendedorismo.

A análise se inicia com a conceituação do instituto da personalidade jurídica para, em seguida, analisar o instituto da desconsideração da personalidade jurídica e suas teorias.

Na sequência, encontra-se conceituada a dissolução irregular da sociedade e a hipótese da desconsideração da sua personalidade, cuja analise e compreensão realizou-se focada em algumas decisões proferidas pelo Superior Tribunal de Justiça, demonstrando o conflito existente dentro da própria corte.

Ao final, procura-se demonstrar a segurança que o procedimento proposto pelo novo CPC proporcionará ao incidente de desconsideração da personalidade jurídica, a fim de respeitar os preceitos constitucionais do contraditório e da ampla defesa.

Revista Brasileira de Direito Empresarial -le-SSN: 2526-0235 | Curitiba | v. 2 | n. 2 | p. 97 - 116 |

Jul/Dez. 2016. 
Assim, o artigo observa a trajetória de uma metodologia dialética e crítica, para compreender os avanços proporcionados pelo novo CPC, tanto para sanar divergências havidas dentro do STJ, quanto para a preservação da autonomia patrimonial da pessoa jurídica, especialmente nas hipóteses de dissolução irregular da sociedade empresária.

\section{PERSONALIDADE JURÍDICA}

Não há como enfrentar o tema proposto no presente artigo sem antes conceituar o que vem a ser a personalidade jurídica, sob pena de omitir um importantíssimo ponto para os objetivos propostos neste ensaio.

O Código Civil enumera as pessoas jurídicas de direito privado em seu art. 44, elencando como tal, a Empresa Individual de Responsabilidade Limitada (EIRELI), as Sociedades Empresárias, as Entidades Religiosas, Fundações, Associações e os Partidos Políticos.

Do rol das pessoas jurídicas de direito privado extraídas do Código Civil, interessa ao estudo do Direito Empresarial a EIRELI e as Sociedades Empresárias.

Na EIRELI, após a integralização de 100 (cem) salários mínimos e do registro empresário na Junta Comercial estadual, a pessoa natural que a instituiu separa o seu patrimônio pessoal do patrimônio da empresa. Desse modo, é possível constatar que a pessoa natural que instituiu a referida modalidade de empresa teve sua personalidade civil adquirida com o nascimento com vida e a EIRELI, por sua vez, adquiriu sua personalidade jurídica a partir do registro empresário na Junta Comercial.

Forma por assim dizer, em um novo ser; um ser estranho à individualidade das pessoas físicas ou jurídicas - que participaram de sua constituição. A sociedade, tanto quanto a empresa individual de responsabilidade limitada (EIRELI), passa a dominar um patrimônio próprio, a possuir órgãos de deliberação e órgãos de execução, enfim, que ditam e fazem cumprir a sua vontade; vontade dela, pessoa jurídica. É, de fato, um "novo ser" (ROCHA FILHO; ROCHA, 2016, p. 348).

Revista Brasileira de Direito Empresarial -le-SSN: 2526-0235 | Curitiba | v. 2 | n. 2 | p. 97 - 116 |

Jul/Dez. 2016. 
Nas sociedades empresárias, os sócios se reúnem e celebram um contrato entre si, o qual será protocolizado na Junta Comercial $^{3}$, precedida, quando necessário, de autorização ou aprovação do poder executivo, averbando-se no registro todas as eventuais alterações por que passar o ato constitutivo, conforme a regra estipulada pelo art. 45 do Código Civil ${ }^{4}$, caracterizando claramente a separação da figura dos sócios da sociedade empresaria, tratando-se, portanto, de uma nova pessoa para o mundo jurídico.

O ordenamento jurídico brasileiro já previa mesmo no Código Civil de 1916, em seu art. 20, que as pessoas jurídicas "têm existência distinta da dos seus membros".

A aquisição da personalidade jurídica é uma consequência e não um requisito para a existência da sociedade, cujo efeito dessa aquisição é uma aptidão genérica de obter direitos e contrair obrigações, como por exemplo, firmar contratos, contratar funcionários, fazer doações, estar em juízo seja na qualidade de autor ou réu, podendo, inclusive, modificar sua estrutura jurídica ou econômica.

Para Cretella Júnior, as principais consequências da personalização da sociedade empresarial são:

A responsabilidade patrimonial, o que significa que o patrimônio da sociedade é autônomo, pertence à própria sociedade, não se confundindo com o patrimônio pessoal dos sócios; somente em situações excepcionais, previstas em lei, poderão os bens do sócio ser executados para o cumprimento de obrigações societárias, como nas dívidas previdenciárias, trabalhistas e fiscais: a titularidade negocial, característica que implica em que, embora os negócios jurídicos sejam celebrados por meio de seu representante legal, é a própria sociedade um dos polos da relação jurídica, e não o representante; e a titularidade processual, o que significa que a própria sociedade tem capacidade processual, podendo demandar e ser demandada em juízo, não se confundindo os autores, réus ou terceiros das ações em que é parte com as pessoas dos sócios ou dos representantes legais. (CRETELLA JÚNIOR, 2004, p. 29).

A aquisição da personalidade jurídica, portanto, contempla a sociedade empresária com sua autonomia patrimonial, não se confundindo com o patrimônio pessoal dos sócios, exceto em situações excepcionais, previstas na legislação.

\footnotetext{
${ }^{3}$ Art. 985. A sociedade adquire personalidade jurídica com a inscrição, no registro próprio e na forma da lei, dos seus atos constitutivos.

${ }^{4}$ Art. 45. Começa a existência legal das pessoas jurídicas de direito privado com a inscrição do ato constitutivo no respectivo registro, precedida, quando necessário, de autorização ou aprovação do Poder Executivo, averbando-se no registro todas as alterações por que passar o ato constitutivo.
}

Revista Brasileira de Direito Empresarial -le-SSN: 2526-0235 | Curitiba | v. 2 | n. 2 | p. 97 - 116 |

Jul/Dez. 2016. 


\subsection{A limitação da responsabilidade do(s) sócio(s) na EIRELI e nas Sociedades Empresárias}

\section{Limitadas}

O ordenamento jurídico brasileiro trouxe a figura de três entes empresariais, quais sejam: a) empresário individual de responsabilidade ilimitada; b) EIRELI - empresa individual de responsabilidade limitada; c) sociedade empresária.

O empresário individual, como o próprio nome diz, trata-se de uma única pessoa que, no exercício da atividade empresarial, executa suas atividades de forma individual e responde ilimitadamente pelos direitos e obrigações contraídas na atividade empresária. Logo, não há separação patrimonial e eventuais dívidas contraídas pela empresa comunicará imediatamente com o patrimônio do empresário individual.

Verçosa apresenta a excepcionalidade de tal modalidade para o exercício da atividade empresária:

Como já se adivinha, o empresário (pessoa natural) será uma exceção quase unânime quanto à forma do exercício da atividade empresarial, uma vez que, preferencialmente, deverão os interessados adotar um dos tipos societários disponíveis (preponderantemente, a sociedade limitada e a sociedade por ações) para o fim de alcançarem limitação patrimonial da responsabilidade diante de terceiros. (VERÇOSA, 2004, p. 187).

Diferentemente, nas sociedades empresárias limitadas e na EIRELI, ambas possuem a responsabilidade dos sócios de natureza limitada, na medida em que os sócios, após a devida integralização do capital social, seguem na administração da sociedade com seus respectivos patrimônios pessoais devidamente separados do patrimônio da sociedade, ou seja, respondem subsidiariamente e no montante do capital social integralizado, preservando a individualidade da sociedade empresária que, com o seu património próprio, responde ilimitadamente pelo seu passivo.

O contrato social da sociedade deverá prever de forma expressa que a responsabilidade dos sócios é limitada à importância total do capital social, conforme ensina Fazzio:

Revista Brasileira de Direito Empresarial -le-SSN: 2526-0235 | Curitiba | v. 2 | n. 2 | p. 97 - 116 |

Jul/Dez. 2016. 
Cada sócio responde, solidariamente, pela integralização de todas as cotas sociais. Uma vez completo o capital social, o patrimônio particular dos sócios não será afetado por débitos da sociedade. Esta responderá ilimitadamente, com seu próprio patrimônio.

Tanto faz tenha o contrato social nascido por escritura particular como por escritura pública. Nuclear é que contenha cláusulas expressas, declarando que a responsabilidade dos sócios é limitada à importância total do capital social. Caso contrário, a sociedade será considerada uma sociedade em nome coletivo. A omissão, portanto, acarretará aos sócios a responsabilização solidária e ilimitada, embora sempre subsidiária. (FAZZIO JUNIOR, 2008, p. 153).

A individualização da sociedade, com a consequente limitação da responsabilidade dos sócios, possui a finalidade de garantir e incentivar o empreendedorismo, assegurando aos sócios que seus patrimônios pessoais não serão diretamente atingidos por dívidas contraídas pela sociedade, uma vez que "a responsabilidade da sociedade perante terceiros é plena, posto que dotadas de autonomia jurídica”. (FAZZIO JÚNIOR, 2008, p. 153).

Porém, a regra da limitação da responsabilidade dos sócios não é absoluta, permitindo algumas exceções, por exemplo, em dívidas de natureza fiscal, tributária e trabalhista.

Além da desconsideração da personalidade jurídica, podemos apontar, ainda as seguintes situações: Os sócios que decidirem contrariamente à lei ou contrato social responderão, ilimitadamente, pelas obrigações sociais decorrentes, isentos é claro, os que formalizarem sua discordância. Nos débitos da dívida ativa, por foça do artigo 135 do CTN, os administradores respondem com seu patrimônio particular se houver inadimplência da sociedade; os sócios respondem solidariamente pelas dívidas de pessoa jurídica perante o INSS (lei 8.620/93); Todos os sócios respondem pessoalmente se a sociedade cessa as atividades sem prévio e legal procedimento dissoluto, existindo débito tributário. (FAZZIO JÚNIOR, 2008, p. 154).

Entretanto, ao presente ensaio interessará aprofundar-se na exceção concernente à desconsideração da personalidade jurídica, prevista no art. 50 do Código Civil $^{5}$ que, conforme defende Requião, trata-se de um instituto a ser utilizado exclusivamente com a finalidade de impedir o abuso dos sócios na administração da sociedade empresária.

Não temos duvidas de que a doutrina, pouco divulgada em nosso país, levada à consideração de nossos tribunais, poderia ser perfeitamente adotada, para impedir a

\footnotetext{
${ }^{5}$ Art. 50. Em caso de abuso da personalidade jurídica, caracterizado pelo desvio de finalidade, ou pela confusão patrimonial, pode o juiz decidir, a requerimento da parte, ou do Ministério Público quando lhe couber intervir no processo, que os efeitos de certas e determinadas relações de obrigações sejam estendidos aos bens particulares dos administradores ou sócios da pessoa jurídica.
}

Revista Brasileira de Direito Empresarial -le-SSN: 2526-0235 | Curitiba | v. 2 | n. 2 | p. 97 - 116 |

Jul/Dez. 2016. 
consumação de fraude contra credores e mesmo contra o Fisco, tendo como escudo a personalidade jurídica da sociedade.

Em qualquer caso, todavia, focalizamos essa doutrina com o propósito de demonstrar que a personalidade jurídica não constitui um direito absoluto, mas está sujeita e contida pela doutrina da fraude contra credores e pela teoria do abuso de direito. (REQUIÃO, 2010, p. 441).

Diga-se isso porque, se por um lado, a limitação da responsabilidade e dos riscos ao empresário incentivam-no ao empreendedorismo, por outro lado, poderá ceder a oportunidade para a prática de atos de abuso de poder por aqueles mesmos sócios que, no exercício da atividade empresarial, poderão praticar atos de confusão patrimonial ou desvio de finalidade.

Em outras palavras, se o "sócio utilizar a separação patrimonial como expediente para fraudar credores, poderá responder pessoalmente pela obrigação que a sociedade assumiu, conforme menciona o art. 50 do Código Civil" (FAZZIO JÚNIOR, 2008, p. 154), aplicando-se a desconsideração da personalidade jurídica da sociedade empresária.

\section{O INSTITUTO DA DESCONSIDERAÇÃO DA PERSONALIDADE JURÍDICA}

A desconsideração da personalidade jurídica também é conhecida pela doutrina como teoria do superamento da personalidade jurídica, doutrina da penetração, ou ainda "esboçada nas jurisprudências inglesa e norte americana, é conhecida no direito comercial como a doutrina do Disregard of legal Entity”. (REQUIÃO, 2010, p. 440).

Trata-se da possibilidade de o Juiz, sempre que, a pedido da parte ou do Ministério Público, quando lhe couber intervir no processo, "penetrar no âmago da sociedade, superando ou desconsiderando a personalidade jurídica, para atingir e vincular a responsabilidade do sócio". (REQUIÃO, 2010, p. 440).

Conforme conceitua Humberto Theodoro Júnior, a desconsideração da personalidade jurídica demandará, necessariamente, a conduta maculada do sócio a fim de prejudicar os credores:

É a denominada disregard doctrine do direito norte-americano, que autoriza o Poder Judiciário a ignorar a autonomia patrimonial entre a empresa e seus sócios ou administradores, sempre que for manipulada para prejudicar os credores. Desta forma, o patrimônio dos sócios é alcançado na reparação de danos provocados pela empresa a

Revista Brasileira de Direito Empresarial -le-SSN: 2526-0235 | Curitiba | v. 2 | n. 2 | p. 97 - 116 |

Jul/Dez. 2016. 
O instituto da desconsideração da personalidade jurídica poderá ocorrer sempre que o patrimônio dos sócios estiver protegido pela pessoa jurídica, logo, estamos falando das sociedades cuja responsabilidade do sócio é limitada.

A presença de tal instituto no ordenamento jurídico brasileiro tonou-se necessária pois, a partir da "autonomia patrimonial reconhecida às pessoas jurídicas, muitos sócios começaram a usá-la como uma espécie de blindagem patrimonial para cometerem fraudes e abusos, afastandose da responsabilidade". (OLIVEIRA, 2014, p. 187).

Significa dizer que, em determinados casos específicos, constatado que os sócios estão agindo com abuso da personalidade jurídica, caracterizado pelo desvio de finalidade ou pela confusão patrimonial, os efeitos da personalização jurídica da sociedade empresária serão temporariamente afastados e, como consequência, o patrimônio dos sócios, que até então estava coberto, responderá pelo cumprimento de uma obrigação específica.

E foi exatamente para isso, para combater a fraude e o abuso de direito, que surgiu a teoria da ou doutrina da desconsideração, ou do superamento, da personalidade jurídica, hoje definitivamente incorporada no nosso Direito, como se pode ver no art. 28 do código de proteção e defesa do consumidor (lei n. 8.078 de 11/09/1990) e do art. 50 do Código Civil Brasileiro para os casos "de abuso da personalidade jurídica, caracterizado pelo desvio de finalidade, ou confusão patrimonial” (ROCHA FILHO; ROCHA, 2016, p. 350).

O abuso da personalidade jurídica poderá se dar pela fraude, caracterizada, notadamente, por aquelas condutas que visam prejudicar terceiros. Dar-se-á ainda, pela confusão patrimonial, a qual diz respeito ao desvirtuamento dos patrimônios da sociedade, de modo que os sócios retiram bens da sociedade colocando-os em nome próprio, esvaziando completamente os bens da sociedade empresária.

$\mathrm{O}$ instituto da desconsideração da personalidade jurídica será sempre excepcional e temporal e "não se trata, é bom esclarecer, de considerar ou declarar nula a personificação, mas de torna-la ineficaz para determinados atos". (REQUIÃO, 2010, p. 440). 
Ressalta-se que a desconsideração da personalidade jurídica não objetiva invalidar os atos constitutivos de uma sociedade, muito menos dissolvê-la. $\mathrm{O}$ que se pretende é tornar ineficazes os atos realizados pela sociedade (e imputáveis aos sócios), quando eles forem praticados em descumprimento à função social da empresa. (DONIZETTI, 2016, p. $328)$.

É excepcional, porque sua utilização depende do preenchimento de certos requisitos, caracterizados pelo "abuso sustentado em dolo, fraude, desvio de finalidade ou confusão patrimonial com a finalidade de prejudicar terceiros". (ROCHA FILHO; ROCHA, 2016, p. 350).

Será também temporal, pois trata-se de um mero afastamento, um esquecimento da personalidade jurídica da sociedade empresária, sem implicar na extinção ou dissolução da pessoa jurídica que, continua a existir, mas sua personalidade jurídica é afastada momentânea e pontualmente para que o patrimônio dos sócios seja alcançado para saldar dívidas por eles efetivamente contraídas.

Via de regra, a sociedade empresária será dotada de sua personalidade jurídica para executar suas atividades, honrando com seus deveres e direitos de forma independente, motivo pelo qual os pressupostos estipulados no art. 50 do Código Civil deverão ser observados quando do requerimento pela parte interessada na desconsideração da personalidade jurídica, conforme explicita Elpidio Donizetti, acerca dos requisitos objetivo e subjetivo, previstos pelo mencionado artigo.

De acordo com o art. 50 do Código Civil, para a desconsideração da personalidade jurídica são necessários: a) o requisito objetivo, que consiste na insuficiência patrimonial do devedor; e b) o requisito subjetivo, consistente no desvio de finalidade ou confusão patrimonial por meio da fraude ou do abuso de direito. Para a aplicação da teoria da desconsideração não basta estar presente apenas o primeiro requisito. Deve, pois, também estar demonstrada, no caso concreto, a existência de uma conduta culposa do sócio ou a sua intenção abusiva ou fraudulenta de utilizar os bens da sociedade para fins diversos daqueles permitidos em lei (requisito subjetivo). (DONIZETTI, 2016, p. 329).

Cumpre examinar a aplicação do instituto da desconsideração da personalidade jurídica em decorrência da dissolução irregular da sociedade e a possibilidade que o sócio terá de exercer o contraditório, a fim de demonstrar a ausência de abuso na administração da pessoa jurídica, ou seja, o requisito subjetivo estipulado no art. 50 do Código Civil.

Revista Brasileira de Direito Empresarial -le-SSN: 2526-0235 | Curitiba | v. 2 | n. 2 | p. 97 - 116 |

Jul/Dez. 2016. 


\section{UMA BREVE APRESENTAÇÃO DAS TEORIAS QUE TRATAM DA DESCONSIDERAÇÃO DA PERSONALIDADE JURÍDICA}

A doutrina apresenta duas teorias acerca da desconsideração da personalidade jurídica, quais sejam: teoria menor e a teoria maior.

A título de exemplo, o Código de Defesa do Consumidor ${ }^{6}$ contempla a teoria menor, na medida em que, a despeito de prever no caput do art. 28 que a aplicação da desconsideração da personalidade jurídica se caracterizará pelo abuso de poder do sócio, prevê, entretanto, no seu parágrafo $5^{\circ}$ que caso a personalidade jurídica da sociedade se demonstre, de alguma forma, obstáculo ao ressarcimento de prejuízos causados aos consumidores, poderá ser desconsiderada a personalidade da sociedade. ${ }^{7}$

Nas jurisprudências que tratam do direito tributário, trabalhista e crimes ambientais (lei. 9.605/98), também é possível verificar a aplicação da teoria menor, sendo suficiente a simples comprovação da insolvência da pessoa jurídica para o pagamento das suas obrigações. Veja-se, os seguintes precedentes: REsp 279.273, $3^{\text {a }}$ Turma, Relatora Ministra Nancy Andrighi, de 29.03.2004, REsp 1.096.604/DF, 4 ${ }^{\text {a }}$ Turma, Relator Ministro Luis Felipe Salomão, de 16.10.2012 e REsp 1.169.175/DF, de 04.04.2011.

A teoria maior, por sua vez, decorrente do art. 50 do Código Civil ${ }^{8}$ prevê a necessidade da comprovação do abuso de poder pelos sócios na administração da sociedade, caracterizada pela fraude ou confusão patrimonial, para se desconsiderar a personalidade jurídica da sociedade.

Seguindo a definição do art. 50 do Código Civil, a Lei Antitruste (Lei 12.529/11) aplica a teoria maior, prevendo a aplicação do instituto nas hipóteses de abuso de direito, excesso de poder, infração da lei ou ato ilícito, violação dos estatutos ou contrato social, falência, insolvência, encerramento ou inatividade provocada por má administração.

\footnotetext{
${ }^{6}$ Art. 28. O juiz poderá desconsiderar a personalidade jurídica da sociedade quando, em detrimento do consumidor, houver abuso de direito, excesso de poder, infração da lei, fato ou ato ilícito ou violação dos estatutos ou contrato social. A desconsideração também será efetivada quando houver falência, estado de insolvência, encerramento ou inatividade da pessoa jurídica provocados por má administração.

${ }^{7} \S 5^{\circ}$ Também poderá ser desconsiderada a pessoa jurídica sempre que sua personalidade for, de alguma forma, obstáculo ao ressarcimento de prejuízos causados aos consumidores.

${ }^{8}$ Art. 50. Em caso de abuso da personalidade jurídica, caracterizado pelo desvio de finalidade, ou pela confusão patrimonial, pode o juiz decidir, a requerimento da parte, ou do Ministério Público quando lhe couber intervir no processo, que os efeitos de certas e determinadas relações de obrigações sejam estendidos aos bens particulares dos administradores ou sócios da pessoa jurídica.
}

Revista Brasileira de Direito Empresarial -le-SSN: 2526-0235 | Curitiba | v. 2 | n. 2 | p. 97 - 116 |

Jul/Dez. 2016. 
Importante ressaltar que a teoria menor é uma exceção e que o ordenamento jurídico pátrio aplica, como regra, a teoria maior da Desconsideração, conforme se infere das decisões do Superior Tribunal de Justiça.

\section{DESCONSIDERAÇÃO DA PERSONALIDADE JURÍDICA NA DISSOLUÇÃO IRREGULAR DA SOCIEDADE NA VISÃO DO STJ}

Na dissolução regular da sociedade empresária, as atividades são paralisadas para a liquidação das dívidas. Trata-se do período no qual a sociedade realiza o seu ativo e liquida o passivo, ou seja, transforma todo o seu patrimônio em dinheiro para quitar as dívidas contraídas com seu universo de credores.

Em seguida, caberá aos sócios preencher as formalidades legais para o registro e a baixa da sociedade empresária junto às autoridades competentes, ensejando, consequentemente, a regular extinção da pessoa jurídica.

Por outro lado, a dissolução irregular da sociedade ocorre quando os sócios encerram a atividade empresária sem as formalidades legais exigidas, bem como sem saldar seu passivo financeiro, sejam eles funcionários, fornecedores, consumidores ou o fisco.

Decorrendo tal situação, na qual ficará caracterizada a insolvência financeira da sociedade e, portanto, a ausência de seu ativo financeiro para quitar seus débitos, os credores viram-se para a pessoa e patrimônio dos sócios.

Conforme explorado neste ensaio, a pessoa jurídica tem personalidade distinta da dos seus sócios, razão pela qual o patrimônio dos sócios não responde diretamente pelas dívidas contraídas pela sociedade empresária.

A questão é se a desconsideração da personalidade jurídica aplica-se como regra imediata nas hipóteses de dissolução irregular da sociedade empresária, sem antes examinar a maneira como a administração se portou.

É de se ressaltar que os tribunais pátrios, bem como o próprio Superior Tribunal de Justiça, enfrentam a situação com muita controvérsia como, por exemplo, pode se verificar no julgamento do Agravo Regimental no Agravo em Recurso Especial n. 516.220-RS, relatado pelo

Revista Brasileira de Direito Empresarial -le-SSN: 2526-0235 | Curitiba | v. 2 | n. 2 | p. 97 - 116 |

Jul/Dez. 2016. 
Ministro Humberto Martins, entendendo pela necessária vinculação entre o encerramento irregular da empresa e a imediata desconsideração da personalidade jurídica:

A desconsideração da personalidade jurídica, com a consequente invasão no patrimônio dos sócios para fins de satisfação de débitos da empresa, é medida de caráter excepcional sendo apenas admitida nas hipóteses expressamente previstas no art. 135 do CTN ou nos casos de dissolução irregular da empresa, que nada mais é que infração à lei. No caso dos autos, o Tribunal de origem, quando apreciou a questão, reconheceu que houve o encerramento irregular da empresa. (BRASIL, 2014).

Por outro lado, verifica-se na decisão dos Embargos de Divergência em Recurso Especial 1.306.553-SC, relatado pela Ministra Maria Isabel Gallotti, entendimento diverso, uma vez que, tal vinculação imediata conduziria ao fim da autonomia patrimonial da pessoa jurídica:

Para a aplicação da teoria maior da desconsideração da personalidade social, exige-se o dolo das pessoas naturais que estão por trás da sociedade, desvirtuando-lhe os fins institucionais e servindo-se os sócios ou administradores desta para lesar credores ou terceiros. É a intenção ilícita e fraudulenta, portanto, que autoriza, nos termos da teoria adotada pelo Código Civil, a aplicação do instituto em comento... Assim, a ausência de intuito fraudulento ou confusão patrimonial afasta o cabimento da desconsideração da personalidade jurídica, ao menos quando se tem o Código Civil como o microssistema legislativo norteador do instituto, a afastar a simples hipótese de encerramento ou dissolução irregular da sociedade como causa bastante para a aplicação do disregard doctrine. Não se quer dizer com isso que o encerramento da sociedade jamais será causa de desconsideração de sua personalidade, mas que somente o será quando sua dissolução ou inatividade irregulares tenham o fim de fraudar a lei, com o desvirtuamento da finalidade institucional ou confusão patrimonial... Em síntese, a criação teórica da pessoa jurídica foi avanço que permitiu o desenvolvimento da atividade econômica, ensejando a limitação dos riscos do empreendedor ao patrimônio destacado para tal fim. Abusos no uso da personalidade jurídica justificaram, em lenta evolução jurisprudencial, posteriormente incorporada ao direito positivo brasileiro, a tipificação de hipóteses em que se autoriza o levantamento do véu da personalidade jurídica para atingir o patrimônio de sócios que dela dolosamente se prevaleceram para lesar credores. Tratando-se de regra de exceção, de restrição ao princípio da autonomia patrimonial da pessoa jurídica, a interpretação que melhor se coaduna com o artigo 50 do Código Civil é a que relega sua aplicação a casos extremos, em que a pessoa jurídica tenha sido mero instrumento para fins fraudulentos por aqueles que a idealizaram, valendo-se dela para encobrir os ilícitos que propugnaram seus sócios ou administradores. Entendimento diverso conduziria, no limite, em termos práticos, ao fim da autonomia patrimonial da pessoa jurídica, ou seja, regresso histórico incompatível com a segurança jurídica e com o vigor da atividade econômica. Com esses fundamentos, não estando consignado no acórdão estadual que a dissolução da sociedade tinha por fim fraudar credores ou ludibriar terceiros, não se configurando, portanto, o desvio de finalidade social ou confusão patrimonial entre sociedade e sócios ou administradores, acolho os embargos de divergência para que prevaleça a tese adotada pelo acórdão paradigma e, por conseguinte, restabelecer o acórdão especialmente recorrido. (BRASIL, 2013).

Revista Brasileira de Direito Empresarial -le-SSN: 2526-0235 | Curitiba | v. 2 | n. 2 | p. 97 - 116 |

Jul/Dez. 2016. 
No mesmo sentido, observa-se decisão proferida no Recurso Especial n. 1.200.850/SP Relator Ministro Massami Uyeda, afastando a teoria menor da desconsideração da personalidade jurídica, cujo trecho segue abaixo:

A responsabilização dos administradores e sócios pelas obrigações imputáveis à pessoa jurídica, em regra, não encontra amparo tão-somente na mera demonstração de insolvência para o cumprimento de suas obrigações (Teoria menor da desconsideração da personalidade jurídica). Faz-se necessário para tanto, ainda, ou a demonstração do desvio de finalidade (este compreendido como o ato intencional dos sócios em fraudar terceiros com o uso abusivo da personalidade jurídica), ou a demonstração da confusão patrimonial (esta subentendida como a inexistência, no campo dos fatos, de separação patrimonial do patrimônio da pessoa jurídica ou de seus sócios, ou, ainda, dos haveres de diversas pessoas jurídicas. (BRASIL, 2010).

Vale observa a decisão proferida no Agravo Regimental no Agravo em Recurso Especial nº 819.899-SP, Relatora Ministra Assusete Magalhães, de 26/02/2016, apontando que, a ausência de ativos financeiros disponíveis nas contas da empresa executada não configura, por si só, reconhecimento de gestão fraudulenta da atividade empresária.

O fato de não haver ativos financeiros disponíveis nas contas da empresa executada, por si só, não autoriza o reconhecimento de gestão fraudulenta da atividade comercial. Pelo que se verifica dos documentos que instruem o agravo não foram realizadas diligências em busca de bens que pudessem satisfazer a execução, bem como não houve demonstração documental da efetiva utilização pela empresa das contas bancárias pessoais dos sócios. Tudo não passa, por ora, de presunção. A desconsideração da personalidade jurídica da empresa é exceção que só pode ser determinada nos casos específicos descritos na lei. Vale dizer, apenas podem ser responsabilizados os sócios que, dirigindo ou gerenciando a sociedade, atuem com excesso de poderes ou infração da lei, contrato social ou estatuto. (BRASIL, 2016).

A controvérsia estabelecida entre as decisões apresentadas, existem na medida em que a primeira aplica a teoria menor, entendendo que a dissolução irregular da sociedade, por si só, configura ato ilegal. As demais decisões, ao revés, aplicam a teoria maior, examinando preliminar e cuidadosamente a conduta do sócio na administração da sociedade, a qual configurase regra geral no direito Brasileiro, conforme se constata da leitura do trecho abaixo, extraído do Recurso Especial 1315110/SE, Relatora Ministra Nancy Andrighi:

Na legislação pátria, todavia, adotou-se, como regra geral, a Teoria Maior da Desconsideração, segundo a qual a mera demonstração de estar a pessoa jurídica insolvente para o cumprimento de suas obrigações não constitui motivo suficiente para a

Revista Brasileira de Direito Empresarial -le-SSN: 2526-0235| Curitiba | v. 2 | n. 2 | p. 97 - 116 |

Jul/Dez. 2016. 
desconsideração da personalidade jurídica. Exige-se, portanto, para além da prova de insolvência, ou a demonstração de desvio de finalidade, ou a demonstração de confusão patrimonial.

Assim, em virtude da adoção da Teoria Maior da Desconsideração, é necessária a comprovação do desvio de finalidade ou a demonstração de confusão patrimonial. É, necessário, portanto, comprovar que alguém - via de regra, um gerente ou administrador, praticou ato reconhecido como fraudulento ou abusivo. (BRASIL, 2012a).

Inexistido, portanto, comprovação de ato intencional dos sócios de fraudar terceiros com o uso abusivo da personalidade jurídica, ou evidenciada a confusão patrimonial, não é cabível a responsabilidade pessoal do sócio, sob pena de se extinguir a autonomia patrimonial da pessoa jurídica, caracterizando relevante ofensa à segurança jurídica.

Ademais, conforme decisões acima apresentadas, a mera demonstração de insolvência ou dissolução irregular da empresa, por si só, não enseja a desconsideração da personalidade jurídica, sendo possível citar ainda os seguintes julgados: (AREsp n 676.391, Relator Ministro João Otávio de Noronha, além de REsp n 1.325.663/SP, relatora Ministra Nancy Andrighi, Terceira Turma, DJe de 24/6/2013 e AgRg no REsp n ${ }^{\circ}$ 1.225.840/MG, relator Ministro Raul Araújo, Quarta Turma, DJe de 27/2/2015).

O novo Código de Processo Civil, por sua vez, veio de encontro aos julgados da Corte Superior, na medida em que, sendo o instituto da desconsideração da personalidade jurídica tratado como uma nova modalidade de intervenção de terceiros, demandará a fundamentação do pedido, bem como o exercício da ampla defesa e do contraditório pelas partes.

\section{O NOVO CÓDIGO DE PROCESSO CIVIL E O INCIDENTE DA DESCONSIDERAÇÃO DA PERSONALIDADE JURÍDICA}

A aplicação da teoria menor nos pleitos de desconsideração da personalidade jurídica, bem como a ausência de oportunidade do exercício do contraditório e da ampla defesa pelo sócio, pode levar o julgador a decisões precipitadas, prejudicando direitos adquiridos da sociedade empresária (autonomia patrimonial) e os direitos dos sócios (separação patrimonial).

Antes do advento do novo código de processo civil (CPC), os pedidos de desconsideração da personalidade jurídica eram apresentados em juízo mediante simples petição

Revista Brasileira de Direito Empresarial -le-SSN: 2526-0235| Curitiba | v. 2 | n. 2 | p. $97-116$ |

Jul/Dez. 2016. 
nos autos pela parte interessada e, muita das vezes, inaudita altera parte, os sócios eram surpreendidos com a perda do seu patrimônio para garantir execução movida contra a sociedade.

\begin{abstract}
A despeito da previsão na lei material, o instituto carecia de regulação processual. Assim, coube à jurisprudência dar forma à desconsideração. Entendiam os tribunais que ela poderia ocorrer incidentalmente nos próprios autos da execução, sem a necessidade de ajuizamento de ação própria. Demonstrando o credor estarem presentes os requisitos legais, o juiz deveria levantar o véu da personalidade jurídica para que o ato de expropriação atingisse os bens particulares de seus sócios, de forma a impedir a concretização de fraude à lei ou contra terceiros. Somente após a desconsideração, os sócios eram chamados a integrar a lide e interpor os recursos cabíveis. O contraditório e a ampla defesa, destarte, eram realizados a posteriori, mas de maneira insatisfatória, já que, em grau de recurso, obviamente, não há como exercer plenamente a defesa assegurada pelo devido processo leal. (THEODORO JÚNIOR, 2016, p. 401).
\end{abstract}

Nesse sentido, antes do advento do novo Código de Processo Civil, o Superior Tribunal de Justiça, por ocasião do voto do Relator Ministro Luís Felipe Salomão, no REsp 1.096.604/DF, se posicionou entendendo ser desnecessário o estabelecimento do contraditório nas hipóteses de desconsideração da personalidade jurídica, dispensando-se, inclusive, a citação dos sócios, em desfavor de quem foi superada a pessoa jurídica, conforme trecho do argumento abaixo:

A desconsideração da personalidade jurídica é instrumento afeito a situações limítrofes, nas quais a ma-fé, o abuso da personalidade jurídica ou a confusão patrimonial estão revelados, circunstancia que reclamam, a toda evidência, providência expedita por parte do judiciário. Com efeito, exigir o amplo e prévio contraditório em ação própria para tal mister, no mais das vezes, redundaria em esvaziamento do instituto nobre. 2. A superação da pessoa jurídica afirma-se como um incidente processual e não como um processo incidente, razão pela qual pode ser deferida nos próprios autos, dispensando-se também a citação dos sócios, em desfavor de quem foi superada a pessoa jurídica, bastando a defesa apresentada a posteriori, mediante embargos, impugnação ao cumprimento da sentença ou exceção de pré-executividade. (BRASIL, 2012b).

Acertadamente evoluiu o novo CPC, trazendo-nos art. 133 a 137 duas oportunidades para se requerer a desconsideração da personalidade jurídica: a primeira, juntamente com a inicial e, a segunda, em petição autônoma, como incidente processual, protocolada no curso da ação. O incidente da desconsideração da personalidade jurídica trata-se de uma nova modalidade de intervenção de terceiros.

O incidente deve ser requerido pela parte interessada ou pelo Ministério Público. Na petição inicial, o requerente deverá demonstrar o preenchimento dos requisitos legais

Revista Brasileira de Direito Empresarial -le-SSN: 2526-0235| Curitiba | v. 2 | n. 2 | p. 97 - 116 |

Jul/Dez. 2016. 
para a desconsideração da personalidade. O ônus da prova é, portanto, de quem alega. Nesse sentido, a redação reforça a ideia de que desconsideração da personalidade jurídica não pode ser determinada sem uma dilação probatória mínima. (DONIZETTI, 2016, p. 329).

O novo CPC propõe uma ruptura com o sistema anterior, com a implementação de novas práticas, visando garantir maior objetividade às demandas judiciais, privilegiando a celeridade sem perder de vista o respeito ao contraditório e ampla defesa.

A elevação do incidente da desconsideração da personalidade jurídica como uma nova modalidade de intervenção de terceiros nada mais é senão o retrato do espirito do novo CPC, pois com o incidente os sócios terão a oportunidade de manifestarem nos autos antes da decisão do juiz.

O incidente de desconsideração poderá ser instaurado pela parte interessada ou pelo Ministério Público, sendo cabível em todas as fases do processo de conhecimento, no cumprimento de sentença e, inclusive, na execução fundada em título executivo extrajudicial. Por outro lado, não há previsibilidade do incidente ser determinado de ofício pelo juiz.

Privilegiando a teoria maior, o novo $\mathrm{CPC}$, estabelece que o requerimento deverá demonstrar o preenchimento dos pressupostos legais específicos para desconsideração da personalidade jurídica, conforme se depreende do trecho abaixo, extraído da decisão proferida no Agravo Regimental no Agravo em Recurso Especial nº 819.899-SP, Relatora Ministra Assusete Magalhães, de 26/02/2016:

Meras alegações não autorizam a responsabilização automática dos sócios, sendo certo que não há no processo, pelo menos por ora, a demonstração inequívoca de eventual desvio de finalidade ou confusão patrimonial da executada com seus sócios. Assim, não havendo comprovação de que os sócios tenham agido com excesso de poderes ou Infringido à lei, contrato social ou estatuto, incabível a desconsideração da personalidade jurídica. (BRASIL, 2016).

Nessa esteira, a fim de não obter do judiciário uma decisão precipitada, bem como oportunizar a ampla defesa, instaurado o incidente, o sócio ou a pessoa jurídica será citado para manifestar-se e requerer as provas cabíveis no prazo de 15 (quinze) dias. Desse modo, concluída a instrução, se necessária, o incidente será resolvido por decisão interlocutória, da qual caberá agravo.

Revista Brasileira de Direito Empresarial -le-SSN: 2526-0235 | Curitiba | v. 2 | n. 2 | p. 97 - 116 |

Jul/Dez. 2016. 
Na hipótese apresentada neste ensaio, os sócios terão a oportunidade de esclarecer os fatos que levaram à dissolução irregular da sociedade, comprovando, se for o caso, ausência de fraude ou abuso de poder na administração da sociedade, sendo que, se comprovada tal situação, restará inviabilizada a incidência do instituto da desconsideração da personalidade jurídica, conforme entendimento majoritário do Superior Tribunal de Justiça.

\section{CONCLUSÃO}

Conforme se demonstrou a autonomia patrimonial da sociedade empresária aliada a separação patrimonial dos sócios foi um avanço que permitiu o desenvolvimento da atividade econômica, conferindo a limitação dos riscos do empreendedor.

Os sócios no exercício da atividade empresária deverão coordenar as atividades de modo a preservar e oportunizar o cumprimento de todas as obrigações, com o patrimônio da própria sociedade.

Não poderá o sócio, ao revés, aproveitar-se da sociedade para praticar atos de abuso de poder, cometendo fraudes e manejando atos de confusão patrimonial.

Desse modo para se apurar a responsabilidade dos sócios na dissolução irregular da sociedade, deverá o julgador, antes, verificar quais foram as condutas praticadas pelos sócios na administração da sociedade.

Conforme entendimento majoritário do Superior Tribunal de Justiça, o julgador não desconsiderará a personalidade jurídica da sociedade empresária, sem antes comprovar que os sócios agiram com abuso de poder, visando exclusivamente fraudar terceiros.

O advento do novo Código de Processo Civil trouxe um relevante contribuição para o tema em questão pois, regulamentou o trâmite processual do instituto da desconsideração da personalidade jurídica, já reconhecido no campo do direito material há muito tempo.

Conclui-se que a aplicabilidade desconsideração da personalidade jurídica de sociedade dissolvida de forma irregular deverá afastar-se da consequência (dissolução irregular) e fixar seu avaliação nas causas (conduta dos sócios na administração) uma vez que o Código de Processo Civil atribui ao credor que desejar pleitear a desconsideração da personalidade jurídica de determinada sociedade a fundamentação do pleito, de modo a detalhar os pressupostos legais

Revista Brasileira de Direito Empresarial -le-SSN: 2526-0235 | Curitiba | v. 2 | n. 2 | p. 97 - 116 |

Jul/Dez. 2016. 
específicos para desconsideração. Ademais, constatou-se preservado o devido processo legal, na medida em que, permitirá ao sócio exercer o contraditório e ampla defesa a fim de comprovar sua boa fé na administração da sociedade a despeito da dissolução irregular da sociedade empresária.

\section{REFERÊNCIAS}

ARAÚJO, Carlos Roberto Vieira. História do pensamento econômico. São Paulo: Atlas, 1988.

BRASIL. Superior Tribunal de Justiça. Agravo Regimental no Agravo em Recurso Especial n. 516.220-RS. Agravante: Adacir Miguel Berticelli. Agravado: Fazenda Nacional. Relator: Ministro Humberto Martins. 18 de junho de 2014. DJe, 27 jun. 2014. Disponível em: <https://ww2.stj.jus.br/processo/pesquisa/>. Acesso em: 12 set. 2016.

Superior Tribunal de Justiça. Agravo Regimental no Agravo em Recurso Especial $n^{\circ}$ 819.899-SP. Agravante: Fundação Centro de Atendimento Sócio-Educativo ao Adolescente Fundação Casa-SP. Agravado: Fazenda do Estado de São Paulo. Relatora: Ministra Assusete Magalhães. Brasília, 19 de fevereiro de 2016. DJe, 26 fev. 2016. Disponível em: <https://ww2.stj.jus.br/processo/pesquisa/>. Acesso em: 12 set. 2016.

Superior Tribunal de Justiça. Recurso Especial 1.306.553-SC. Embargante: Comércio de Carnes Vale Verde Ltda e outros. Embargado: Frigorífico Rost S/A. Relatora: Ministra Maria Isabel Gallotti. Brasília, 03 de abril de 2013. DJe, 16 abr. 2013. Disponível em: <https://ww2.stj.jus.br/processo/pesquisa/ >. Acesso em: 12 set. 2016.

Superior Tribunal de Justiça. Recurso Especial 1315110/SE. Recorrente: Manuela Araújo Melo. Recorrido: Ferragem Nordeste - Sérgio Luiz Muller Ottoni M P P. Relatora: Ministra Nancy Andrighi. Brasília, 23 de março de 2012a. DJe, 03 abr. 2012. Disponível em: <https://ww2.stj.jus.br/processo/pesquisa/ >. Acesso em: 12 set. 2016.

. Superior Tribunal de Justiça. Recurso Especial n. 1.200.850/SP. Recorrente: Jesus Adib Abi Chedid e outro. Recorrido: Maria Lúcia Freitas Barbosa. Relator: Ministro Massami Uyeda. Brasília, 30 de junho de 2010. DJe, 03 ago. 2010. Disponível em:

<https://ww2.stj.jus.br/processo/pesquisa/ >. Acesso em: 12 set. 2016.

. Superior Tribunal de Justiça. REsp 1.096.604/DF. Embargante: Marcos Vieira dos Santos Paiva e outros. Embargado: Sérgio Fonseca Iannini. Relator: Ministro Luís Felipe Salomão. Brasília, 12 de novembro de 2012b. Disponível em: <https://ww2.stj.jus.br/processo/pesquisa/ >. Acesso em: 12 set. 2016.

COELHO, Fábio Ulhoa. Curso de direito comercial. 12. ed. rev. e atual. São Paulo: Saraiva, 2008. v. 2.

Revista Brasileira de Direito Empresarial -le-SSN: 2526-0235 | Curitiba | v. 2 | n. 2 | p. 97 - 116 | Jul/Dez. 2016. 
COMPARATO, Fábio Konder. Direito empresarial. 1. ed. São Paulo: Saraiva, 1990. O poder de controle na sociedade anônima. 3. ed. Rio de Janeiro: Forense, 1983.

CRETELLA JÚNIOR, José. 1000 perguntas e respostas de Direito Comercial. Rio de Janeiro: Forense, 2004.

DONIZETTI, Elpídio. Curso Didático de Direito Processual Civil. 19. ed. São Paulo: Atlas, 2016.

FAZZIO JUNIOR, Waldo. Manual de Direito Comercial. 9. ed. São Paulo: Atlas, 2008.

GONTIJO, Vinícius José Marques. O empresário no Código Civil brasileiro. Revista dos Tribunais, v. 831, n. 147.

KOURY, Susy Elizabeth Cavalcante. A desconsideração da Personalidade jurídica (Disregard Doctrine) e os Grupos de Empresas. 2. ed. Rio de Janeiro: Forense, 2003.

MARTINS-COSTA, Judith. Função social do contrato. São Paulo: Saraiva, 2004.

OLIVEIRA, Júlio Moraes. Curso de Direito do Consumidor Completo. Belo Horizonte: D’Plácido, 2014.

REQUIÃO, Rubens. Curso de Direito Comercial. 1. ed. São Paulo: Saraiva, 2010.

ROCHA FILHO, José Maria; ROCHA, Gustavo Ribeiro. Teoria Geral da Empresa e Direito Societário. 3. ed. Belo Horizonte: D’Plácido, 2016.

RODRIGUES, Frederico Viana (Coord.). Direito de empresa no novo Código Civil. Rio de Janeiro: Forense, 2004.

ROPPO, Enzo. O contrato. Coimbra: Almedina, 2009.

ROTONDI, Mario. Instituciones de derecho privado. Tradução: Francisco Villavicencio. 1. ed. Madri: Labor, 1953.

SERICK, Rolf. Forma e realtá della persona giuridica. Tradução: Março Vitale. 1. ed. Milão: Giuffré, 1966.

TEPEDINO, Gustavo; SCHEREIBER, Anderson. Os efeitos da Constituição em relação à cláusula da boa-fé no Código de Defesa do Consumidor e no Código Civil. Revista da EMERJ, v. 6, n. 23, 2003.

Revista Brasileira de Direito Empresarial -le-SSN: 2526-0235| Curitiba | v. 2 | n. 2 | p. $97-116$ | Jul/Dez. 2016. 
THEODORO JÚNIOR, Humberto. Curso de Direito Processual Civil. 57. ed. Rio de Janeiro: Forense, 2016. v. 1.

VERÇOSA, Haroldo Malheiros Duclerc. Curso de direito comercial. São Paulo: Malheiros, 2004.

Revista Brasileira de Direito Empresarial -le-SSN: 2526-0235| Curitiba | v. 2 | n. 2 | p. 97 - 116 | Jul/Dez. 2016. 